\title{
A STLDY OF DOUBLE SALTS IN STANDARD CELLS
}

\author{
BY G. F. LIPSCOMB AND G. A. HULETT
}

There are only two combinations which have been found to possess the qualifications necessary for a standard of electromotive force. The Clark cell and the Weston cell.

$$
\begin{array}{l|l:l|l}
\mathrm{Zn} \mathrm{Amg} & \mathrm{ZnSO}_{4} \mathrm{H}_{2} \mathrm{O} & \mathrm{Hg}_{2} \mathrm{SO}_{4} & \mathrm{Hg} \text { and } \\
\mathrm{Cd} \text { Amg } & \mathrm{CdSO}_{4} 8 / 3 \mathrm{H}_{2} \mathrm{O} & \mathrm{Hg}_{2} \mathrm{SO}_{4} & \mathrm{Hg} .
\end{array}
$$

This situation is due to several factors. A metal in the solid state does not exhibit a constant or reproducible potential against a solution of its salts; but mercury, a liquid, does, and also liquid amalgams. Consequently we are restricted to mercury and amalgams. Further, if the metals form more than one series of salts, difficulties are encountered. It also seems to be necessary that the metals used should have a relatively large solubility in mercury, and be as far removed from mercury in the voltaic series as possible, but should not liberate hydrogen from solution. Now zinc and cadmium are the only two metals which fulfil these conditions, and cadmium more nearly so than zinc, which slowly liberates hydrogen. The electrolyte about the mercury electrode must contain a mercury salt, and this must have the same acid radical as the base metal. The sulphate of mercury has been practically exclusively used, but the chloride is also suitable, as we have shown in a previous paper. If mercury sulphate is used on mercury electrode, the sulphate of the metal of the anode must be used for the solution. So it will be seen that in fact, the possibilities for standard cells are quite limited and especially, as it is also necessary that the base metal salts used be well defined, stable and form good crystals. It is, however, possible to use double salts of the base metal, that is, $\mathrm{ZnSO}_{4} \mathrm{~K}_{2} \mathrm{SO}_{4} .6 \mathrm{H}_{2} \mathrm{O}$ which is a stable salt and crystallizes in large well-formed crystals. Also there are the following possibilities: Cadmium sulphate forms a double salt with potassium sulphate, which has the composi- 
tion $\mathrm{K}_{2} \mathrm{SO}_{4} \mathrm{CdSO}_{4} \cdot 6 \mathrm{H}_{2} \mathrm{O}$. So it is obvious that this double salt can be used in the place of $\mathrm{CdSO}_{4} .8 / 3 \mathrm{H}_{2} \mathrm{O}$. Further the two chlorides of cadmium and zinc form well-defined double salt crystals with potassium chloride of the composition $\mathrm{ZnCl}_{2} 2 \mathrm{KCl}$ and $\mathrm{CdCl}_{2} \cdot 6 \mathrm{H}_{2} \mathrm{O}$. These double chloride salts also offer some possibilities for their use in standard cells.

Furthermore, with one double salt we may have three different saturated cells, viz.:

$$
\begin{aligned}
& \text { (1) } \mathrm{ZnAmg}\left\{\mathrm{K}_{2} \mathrm{SO}_{4} \mathrm{ZnSO}_{4} \cdot 6 \mathrm{H}_{2} \mathrm{O}\right\} \mathrm{Hg}_{2} \mathrm{SO}_{4} \mid \mathrm{Hg} \\
& \text { (2) } \mathrm{ZnAmg}\left\{\begin{array}{l}
\mathrm{K}_{2} \mathrm{SO}_{4} \mathrm{ZnSO}_{4} \cdot 6 \mathrm{H}_{2} \mathrm{O} \\
\mathrm{ZnSO}_{4} \cdot 7 \mathrm{H}_{2} \mathrm{O}
\end{array}\right\} \mathrm{Hg}_{2} \mathrm{SO}_{4} \mid \mathrm{Hg} \\
& \text { (3) } \mathrm{ZnAmg}\left\{\begin{array}{l}
\mathrm{K}_{2} \mathrm{SO}_{4} \mathrm{ZnSO}_{4} \cdot 6 \mathrm{H}_{2} \mathrm{O} \\
\mathrm{K}_{2} \mathrm{SO}_{4}
\end{array} \mathrm{Hg}_{2} \mathrm{SO}_{4} \mid \mathrm{Hg}\right.
\end{aligned}
$$

where the double salt or double salt and simple salt, with their saturated solutions, represent reproducible equilibrium points in the phase rule diagram. In view of the reproducibility and constancy of cells of this character, liquid metallic electrodes and well-defined soluble salts, this field offers the possibility of an interesting study of double salts, as well as the thermodynamics of such cells.

It was necessary before employing double salts, in such combinations to investigate the phase relationships of the respective salts in order to determine the limits of concentration over which they were stable at a given temperature, their temperature range of stability, and also their behavior toward aqueous solutions; in other words, whether the double salt existed in stable equilibrium with its own saturated solution.

To this end the three-component system of the salt, the corresponding potassium salt, and water, was studied. In order to elucidate the phase rule study of double salts, a typical diagram is given. The ordinates represent reacting weights of one salt, and the abscissae the reacting weights of the other salt, both in a constant amount of $\mathrm{H}_{2} \mathrm{O}$.

In most cases addition of a salt to a saturated solution of second salt, either the acid or the basic radical being common, produces a decrease in the solubility of the second salt. The 
three branches in Fig. I, (AC), (CD), (DB), represent the change in concentration, when one of the salt components is added continuously to a solution, kept at a constant temperature. The points (A) and (B) in the diagram represent the number of grams respectively of the anhydrous salts in Ioo grams of their saturated solutions. Along the curve (AC) the salt (A) is present in the solid phase with increasing amounts of (B) in solution; and the salt (B) along (DB). The curve (CD) represents the saturated solution of the double salt with varying amounts, one or the other of $(A)$ or $(B)$ in solution, except at the point $(\mathrm{E})$ where the line $(\mathrm{OE})$, bisecting the angle (AOB), cuts the curve. Here only does the solution contain equimolecular quantities of (A) and (B) which is the saturated solution of the pure double salt. (CD) then represents the composition of all the saturated solutions which are in equilibrium

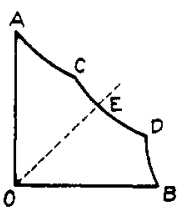

Fig. I

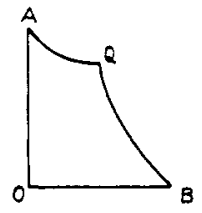

Fig. 2 with the double salt at that temperature. If the temperature is continuously changed this part of the curve disappears and finally a temperature is reached where the double salt does not exist in stable equilibrium with any solution, and under such conditions the double salt always decomposes. The curve then takes the form given in Fig. 2. The solution is in equilibrium with the solid phase (A) along (AQ), and the salt (B) along $(Q B)$. At $(Q)$ the solution is in equilibrium with the two salts $(A)$ and $(B)$.

Proceeding from (A) the double salt appears as solid phase at (C) and further addition of (B) causes no change in the concentration of the solution, until all of (A) in the solid phase has been converted into double salt. When this has happened the system will pass along the line (CD) until at (D), (B) appears as solid phase, and further addition of this component produces no change in the concentration of the solution.

\section{Experimental}

For the phase rule study the following general procedure was adopted: Solutions of varying concentration of the 
potassium salt were taken, and rotated with excess of the corresponding zinc or cadmium salts in sealed tubes $I_{5} \times 2 \mathrm{~cm}$. Analyses of the liquid phase were made from time to time to determine when equilibrium had been attained, and in all cases the rotation was continued several days beyond this point. In certain cases the reverse procedure was adopted, the potassium salt was added to a solution of the zinc or cadmium salt and rotated till equilibrium was established. The change from single to double salt was in all cases found to be a fairly rapid one. The solutions thus obtained were analyzed by the following method:

A weighed amount of the solution was electrolyzed in a platinum crucible using mercury as cathode according to the procedure described by Hulett and Perdue. ${ }^{1}$ The residual solution was evaporated in a platinum dish and the potassium weighed as sulphate. Careful tests were made in all cases to insure that electrolytic deposition of the cadmium and zinc was complete. In the case of the chloride the above procedure was employed after conversion of the chloride to sulphate or an alternative method was in some cases adopted, and gave concordant results. ${ }^{2}$

As a control the chloride content was estimated volumetrically in a portion of the solution by the Volhard method in the presence of acid, and the zinc was estimated in a further portion by precipitation and weighing as zinc ammonium phosphate.

The details of the cell construction were in all cases similar to the one described previously for the $\mathrm{CdCl}_{2} \cdot 2{ }^{1} / 2 \mathrm{H}_{2} \mathrm{O}$ cell, and call for no further description here.

The phase relationship ascertained, it only remained to prepare quantities of the respective salts, to construct a series of such cells, and to determine their respective electromotive forces, and their temperature coefficient. The three following combinations were studied particularly:

(I) $\mathrm{ZnHg}\left(\mathrm{K}_{2} \mathrm{SO}_{4} \mathrm{ZnSO}_{4} \cdot 6 \mathrm{H}_{2} \mathrm{O}\right), \mathrm{Hg}_{2} \mathrm{SO}_{4}: \mathrm{Hg}$

'Jour. Phys. Chem., 15, 155 1911).

2 Ibicl, 17, 755 (19ז3). 


\section{(2) $\mathrm{ZnHg}\left\{\begin{array}{c}\mathrm{K}_{2} \mathrm{SO}_{4} \mathrm{ZnSO}_{4} \cdot 6 \mathrm{H}_{2} \mathrm{O} \\ \mathrm{K}_{2} \mathrm{SO}_{4}\end{array}\right\}, \mathrm{Hg}_{2} \mathrm{SO}_{4}, \mathrm{Hg}$ \\ (3) $\mathrm{ZnHg}\left\{\begin{array}{c}\left.\mathrm{K}_{2} \mathrm{SO}_{4} \mathrm{ZnSO}_{4} \cdot 6 \mathrm{H}_{2} \mathrm{O}\right\} \\ \mathrm{ZnSO}_{4} \cdot 7 \mathrm{H}_{2} \mathrm{O}\end{array}\right\}, \mathrm{Hg}_{2} \mathrm{SO}_{4} ! \mathrm{Hg}$ \\ Results of the Work}

The three-component system $\mathrm{K}_{2} \mathrm{SO}_{4}, \mathrm{ZnSO}_{4}, \mathrm{H}_{2} \mathrm{O}$ at $25^{\circ}$. The curve obtained in Fig. 3 has three branches

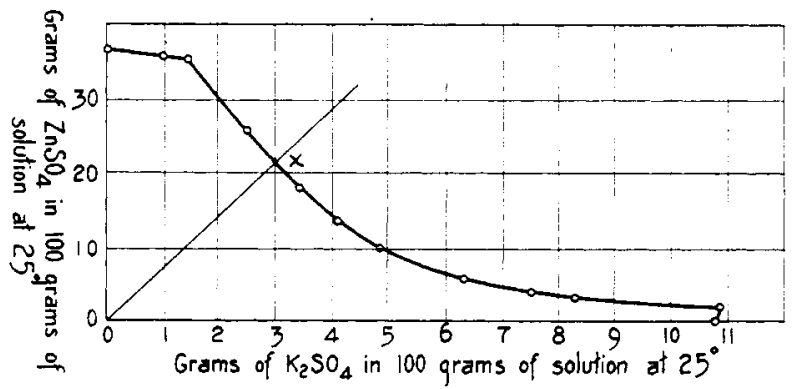

Fig. 3

corresponding to the substance $\mathrm{K}_{2} \mathrm{SO}_{4}$ double salt, and $\mathrm{ZnSO}_{4}$.${ }_{7} \mathrm{H}_{2} \mathrm{O}$ as solid phase in equilibrium. The double salt is capable of stable existence between the range of concentration 38 grams in 100 grams solution, and 128 grams in 100 grams solution. The solubility data from which the curve is plotted are collected in Table I.

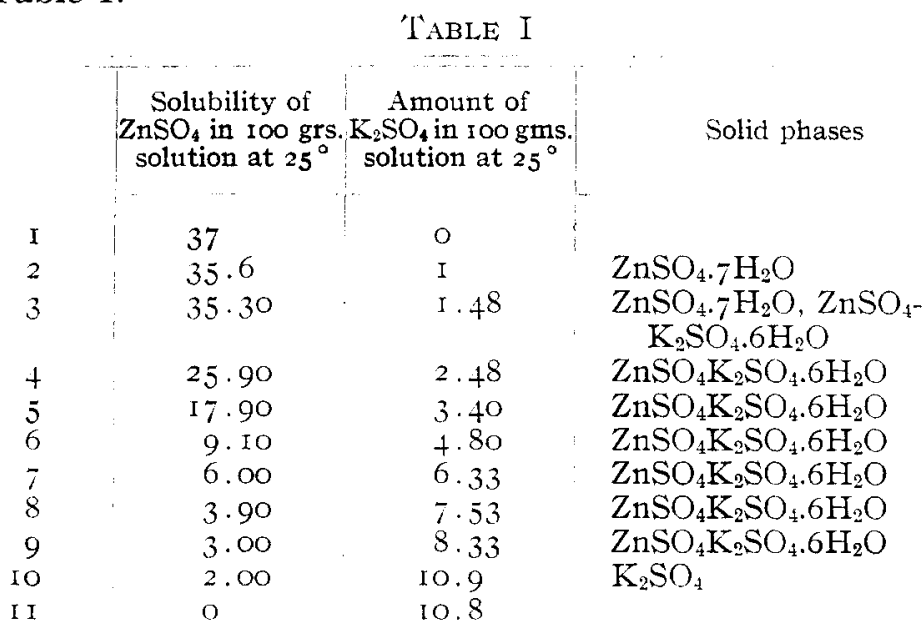


It is evident that the double salt can exist in stable equilibrium with its own saturated aqueous solutions as the line drawn from the origin representing the composition of the salt cuts the curve of the double salt at $\mathrm{X}$.

The three-component system $\mathrm{ZnCl}_{2}, \mathrm{KCl}, \mathrm{H}_{2} \mathrm{O}$ was also investigated. The curves obtained with the solubility data from which the curve in Fig. 4 was constructed are given below.

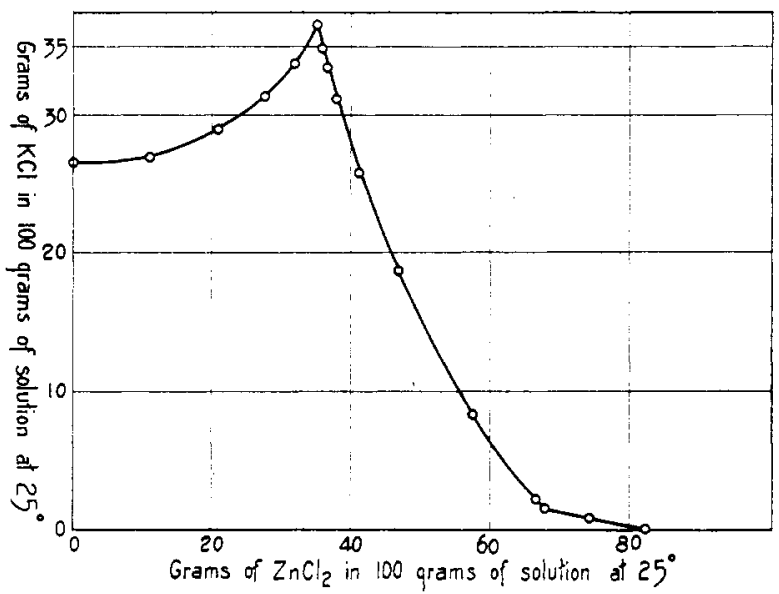

Fig. 4

TABLE II

Solubility of Amounts of $\mathrm{ZnCl}_{2}$ in $100 \mathrm{grs}$. $\mathrm{KCl}$ in 100 grs. solution at $25^{\circ}$ solution at $25^{\circ}$
Solid phase
82

74

$67 \cdot 5$

66.5

64.0

$57 \cdot 5$

46.8

4 I. 0

38

36.5

$35 \cdot 5$

35

31.75

$2 \mathrm{I} \cdot 5$

0
0

0.75

I. 50

2.00

3.33

8.25

I 8.75

$25 \cdot 75$

3 I . 00

33.50

35.00

36.50

$33 \cdot 75$

29.00

26.5
$\mathrm{ZnCl}_{2}$

$\mathrm{ZnCl}_{2}$ and double salt

Double salt

Double salt

Double salt

Double salt

Double salt

Double salt

Double salt

$\mathrm{KCl}$ and double salt

$\mathrm{KCl}$ 
The electromotive force of the cells containing either the double salt alone or potassium sulphate, and the double salt in the solid phase, varied considerably. Their electromotive forces at $25^{\circ}$ were 1.46965 and $1_{4} 48680$ respectively.

$$
\begin{array}{c|c}
\mathrm{Zn} \text { Amg } & \left(\mathrm{K}_{2} \mathrm{SO}_{4} \mathrm{ZnSO}_{4} \cdot 6 \mathrm{H}_{2} \mathrm{O}\right), \mathrm{Hg}_{2} \mathrm{SO}_{4} \mathrm{Hg} \\
\mathrm{Zn} \text { Amg }\left|\left\{\begin{array}{c}
\mathrm{H}_{2} \mathrm{SO}_{4} \mathrm{ZnSO}_{4} \cdot 6 \mathrm{H}_{2} \mathrm{O} \\
\mathrm{K}_{2} \mathrm{SO}_{4}
\end{array}\right\}, \mathrm{Hg}_{2} \mathrm{SO}_{4}\right| \mathrm{Hg}
\end{array}
$$

The saturated solutions of the double salt alone or potassium sulphate, and the double salt, seem to hydrolyze the depolarizer, and this fact may account for the inconstancy of these two combinations. On the other hand, if the combination

$$
\mathrm{ZnAmg}\left|\left\{\begin{array}{l}
\left.\mathrm{K}_{2} \mathrm{SO}_{4} \mathrm{ZnSO}_{4} \cdot 6 \mathrm{H}_{2} \mathrm{O}\right\} \\
\mathrm{ZnSO}_{4} \cdot 7 \mathrm{H}_{2} \mathrm{O}
\end{array}\right\}, \mathrm{Hg}_{2} \mathrm{SO}_{4}\right| \mathrm{Hg}
$$

is used, this difficulty of hydrolysis of the $\mathrm{Hg}_{2} \mathrm{SO}_{4}$ is overcome. The electromotive force of this cell was found to be I.41976 at $25^{\circ}$, with a negative temperature coefficient of 0.00133 .

Since the investigation on the cadmium chloride cell, employing calomel as depolarizer with cadmium chloride as salt, gave results which for constancy and reproducibility left nothing to be desired, it was decided to investigate cells containing the chloride double salt. The constancy and reproducibility of the combination $\mathrm{Cd} \mathrm{Amg} \mid\left(2 \mathrm{KClCdCl}_{2}\right.$.$\left.6 \mathrm{H}_{2} \mathrm{O}\right), \mathrm{Hg}_{2} \mathrm{Cl}_{2} \mid \mathrm{Hg}$ is given in Table III:

\begin{tabular}{|c|c|c|c|c|c|}
\hline $\begin{array}{l}\text { No. } \\
\text { of } \\
\text { cell }\end{array}$ & $\begin{array}{c}\text { March } 9, \\
1915 \\
25^{\circ}\end{array}$ & $\begin{array}{l}\text { March I 2, } \\
\text { I915 } \\
25^{\circ}\end{array}$ & $\begin{array}{l}\text { May I, } \\
\text { I9I } 5 \\
25^{\circ}\end{array}$ & $\begin{array}{c}\text { June I, } \\
1915^{\circ} \\
25^{\circ}\end{array}$ & $\begin{array}{c}\text { Aug. } 8 \text {, } \\
\text { I9I } 5 \\
25^{\circ}\end{array}$ \\
\hline$I$ & 0.70505 & 0.70506 & 0.70506 & 0.70504 & 0.70504 \\
\hline 2 & 0.70503 & 0.70504 & 0.70505 & 0.70505 & 0.70504 \\
\hline & $\underset{\mathrm{I} 5^{\circ}}{\operatorname{March}}{ }^{\circ}$ & $\underset{\text { I } 5^{\circ}}{\text { March I5 }}$ & & & \\
\hline I & 0.70355 & 0.70355 & - & - & 一 \\
\hline 2 & $0.7035^{\circ}$ & 0.70350 & - & - & - \\
\hline & $\operatorname{April}_{30^{\circ}} 2$ & ${ }_{30^{\circ}}{ }^{\circ}$ & $\begin{array}{c}\text { April } \\
30^{\circ}\end{array}$ & & \\
\hline I & 0.70575 & 0.70577 & 0.70577 & - & - \\
\hline 2 & 0.70570 & 0.70570 & 0.70572 & - & - \\
\hline
\end{tabular}

\section{TABLE III}

Date of Construction, March 4, I9I5 
The temperature coefficient of this combination was +o.ooor 5 at $18^{\circ} \mathrm{C}$.

The electromotive force of the combination $\mathrm{Zn} \mathrm{Amg}$ $\left(2 \mathrm{KClZnCl}_{2} .6 \mathrm{H}_{2} \mathrm{O}\right), \mathrm{Hg}_{2} \mathrm{Cl}_{2} \mid \mathrm{Hg}$ was 1.01857 at $25^{\circ}$. The double salt although crystallized in a beautiful form when brought into solution, did not seem to be stable and hydrolyzed.

Laboratory of Physical Chemistry

Princeton, N. J., Ang., I9I5 